\title{
STUDIES ON THE ACID ACTIVATION OF BRAZILIAN SMECTITIC CLAYS
}

\section{Francisco R. Valenzuela Díaz and Pérsio de Souza Santos}

Departamento de Engenharia Metalúrgica e de Materiais, Escola Politécnica, Universidade de São Paulo, CP 61548, 05424-970 São Paulo - SP

Recebido em 15/7/99; aceito em 19/01/01

\begin{abstract}
STUDIES ON THE ACID ACTIVATION OF BRAZILIAN SMECTITIC CLAYS. Fuller's earth and acid activated smectitic clays are largely used as bleaching earth for the industrial processing of vegetable, animal and mineral oils and waxes. The paper comments about the nomenclature used for these materials, the nature of the acid activation of smectitic clays (bentonites), activation laboratory procedures and presents a review of the acid activation of bentonites from 20 deposits from several regions of Brazil. The activated clays were tested and show good decolorizing power for soybean, castor, cottonseed, corn and sunflower oils.
\end{abstract}

Keywords: acid activation; bleaching earth; smectitic Brazilian clays.

\section{INTRODUCTION}

Brazil is a large producer, consumer and exporter of vegetable oils and of other types (animal, fish oils; waxes); for their industrial processing, decolorization is made by two types of clay materials: (a) fuller's earth"; (b) acid treated smectitic clays or acid activated bentonites. The later receives a variety of names: acid treated or acid leached smectitic clays; acid activated clays or bentonites; adsorbent clays; decolorizing clays; bleaching clays or, even, activated fuller's earth. Thermal treatment is used to activate bauxites and palygorskite- sepiolite clays to develop decolorizing ability for lubricating oils and other similar materials.

The Brazilian vegetable oil industries use imported acid activated clays (bentonites) and Brazilian fuller's earth; only in recent years a pair of Brazilian industries started the production of acid activated bentonites for bleaching vegetable oils. However, along the years studies on the acid activation of Brazilian smectites from various bentonite deposits have been conducted by several research groups and their results have appeared in papers and thesis. Araujo and Telles ${ }^{3}$ studied the adsorption of several compounds in oxidised lubricating oils using a fuller's earth and an activated bentonite.

The aim of this paper is to present a review of the more recent studies on the acid activation of Brazilian smectitic clays for decolorizing vegetable oils.

\section{BLEACHING CLAYS}

The best known property of bleaching earth is its high adsorption capacity, which can be enhanced by acid treatment. The increase in specific surface area and pore volume improves the adsorption capacity of metal impurities, phosphatides and color bodies. However, the mechanisms of impurity removal are

"In Brazil, the used definition of fuller's earth is the one given by Ladoo and Myers": "Fuller's earth is an inexact term applied to certain natural clays that have a marked ability to adsorb coloring materials from oils of animals, vegetable and mineral origin". According to Robertson ${ }^{2}$, the first recorded use of fuller's earth (then called cymolean earth) was in Cyprus Island 5000 B.C. Robertson ${ }^{2}$ also reproduced the following given by the U.S. Bureau of Mines when asked by James J. Fallon (formerly from Engelhard) for a precise definition: "Fuller's earth is the kind of material which is used in application where fuller's earth is traditionally used". not always simple and other properties, such as cation exchange capacity (CEC), as well as acid and catalytic properties must be taken into account. The acid properties are responsible for removal of soaps, in addition to the unwanted increase of free fatty acids by splitting trygliceride molecules. The catalytic properties are responsible for the decomposition of peroxides. Finer particle sizes of clays, having greater specific surface areas, produce better bleaching results, but filtration rate and oil retention can be adversely affected. Therefore it is necessary to have tight control of particle size distribution of the bleaching clay to allow an adequate filtration rate, thereby reducing, as much as possible, the level of ultrafine particles.

The bleaching process can be carried out after degumming and deacidifying the vegetable oil, in the case of chemical refining, and after acid degumming in the case of physical refining. The bleaching process is carried out under vacuum, with typical contact temperature in the range of $80-120{ }^{\circ} \mathrm{C}$ and contact time ranging from 20-40 minutes. The dosage of bleaching earth is variable depending on both the process and the oil type. Chemical refining uses $0.5-2 \%$ on a weight basis, while physical refining consumes about $0.25-2 \%$. However darker oils and fats may require as much as $2-4 \%$ to meet final color requirements.

Bleaching clays in either powder or granular form are used for the refining of petroleum products using two main processes: contact and percolation. In the contact process, the recovered oil, paraffin wax or liquid paraffin is previously treated with sulphuric acid to remove acid tar, and after its decantation the bleaching earth is added. In the percolation process, the solvent to be treated is passed through a tower containing a bed of bleaching clay granules. The particle size distribution of the granules is important to minimize the pressure loss of the fluid, avoiding the "closing" of the tower.

Some industrial oils and chemicals that can be treated with bleaching clays are ${ }^{4}$ : industrial triglycerides used in the manufacture of paint varnishes and soaps; mineral oils for special applications including transformer oils, turbine oils and medicinal white oils; paraffin and waxes for use in the food industry; waste oils regenerated for re-refined lubricating oils; rolling oils used as lubricants; solvents, mainly consisting of chlorinated hydrocarbons and surfactants, used for dry cleaning; mined crude sulphur that is treated in a refining process to remove bituminous substances; and aromatic hydrocarbons such as benzene, toluene, and xylene that are treated in a percolation process to remove olefin hydrocarbons. 


\section{NOMENCLATURE}

\section{Acid-Activation vs. Acid-Treatment of the Clay}

Which term would be recommended? The first is traditionally and most commonly used, but it involves the terms "active solid" (or active clay) and "activation of a solid" (or of a clay). The second is purely operational: the clay is treated by an acid, like sulphuric or hydrochloric, under specific experimental conditions. It is part of the more general term "chemical treatment".

It is possible to suggest some definitions for "active" and "activation" based on the literature on the subject even if it is a little bit old. Accordingly to Professor I. B. Cutler "the term active powder may mean different things to different people. In terms of ceramic powders it generally means a sinterable powder". The term "active alumina" may be used in three ways 6 : In catalyst technology it typically means aluminas with high specific surface area (larger than $100 \mathrm{~m}^{2} / \mathrm{g}$ ) and considerable chemical activity. Active alumina in the second sense means an alumina that exhibits a propensity for adsorbing water and other components from gases and liquids. Third: in the ceramic industries (including refractories), active alumina may be used as a contraction for the term "reactive alumina". Reactive aluminas are aluminas that can be sintered more easily than common alumina powders. The phrase "activated alumina" was a registered trademark of ALCOA in 1940; although these aluminas are primarily known as "activated", they are sometimes referred to as "active alumina". Today the phrase applies to any alumina crystal morphology that is porous in structure and produced by thermal dehydroxilation of alumina hydroxides ${ }^{7}$. According to Prof. S.J. Gregg, in the chapter he wrote entitled "Active Solids", "the characteristic properties of an "active solid" tend to appear when the surface area is at least about $1 \mathrm{~m}^{2} / \mathrm{g}$ ". Natural kaolinites and smectites have BET nitrogen surface areas varying from 10 to $25 \mathrm{~m}^{2} / \mathrm{g}$ and from 16 to $97 \mathrm{~m}^{2} / \mathrm{g}$, respectively, without any chemical treatment ${ }^{(9-11)}$; so, they have values of surface areas that correspond to active solids.

The English fuller's earth is a calcium montmorillonite ${ }^{2}$; the American Oil Chemist Society standard of fuller's earth is a calcium montmorillonite and has a BET surface area of 33 $\mathrm{m}^{2} / \mathrm{g}^{12}$. Therefore, they are naturally "active clays". The name of the clay mineral component of the clay is smectite and that type of clay is named bentonite.

"Activation", according to Lamar ${ }^{12}$, is the chemical or physical treatment applied to certain types of clays to develop a capacity to adsorb coloring matter and other impurities in oils (vegetable, animal, and petroleum). According to Prof. S.J. $\mathrm{Gregg}^{8}$, the term "activity" denotes (surface) chemical and physico-chemical reactivity, whose increase is usually traceable to an increase in the surface area of the solid. The preparation of an active solid or the activation of the solid is carried out for a variety of purposes: for use as an adsorbent for gases or for substances in solution; for use as a catalyst; or in order to obtain a high rate of reaction or dissolution in some industrial chemical processes or chemical reactions.

According to Prof. Gregg's concepts, the acid treatment of smectites or bentonites is an "acid activation", because it is used to adsorb the coloring matter dissolved in oil. Also, the surface area is several times larger after the acid-activation, reaching values of 200 to $300 \mathrm{~m}^{2} / \mathrm{g}^{(13,14)}$ in acid-treated clays.

Presently the expressions "activation of a clay or a clay mineral" and "activated clays" cover a wide range of chemical treatments, most of them aimed at producing modifications on the surface of the clay mineral crystals. Besides the acid activated smectites or bentonites the following are some of the treatments used: (a) sodium exchanged smectites ${ }^{(15,16)}$; (b) quaternary ammonium exchanged smectites (organophilic bentonites) ${ }^{17}$; (c) organic clad kaolinites (oleic acid; silanes; organic polymers) ${ }^{18}$; (d) surface modified kaolinites ${ }^{19}$; (e) intercalated inorganic polyhydroxications ${ }^{20}$; (f) pillared smectites $^{(21,22)} ;(\mathrm{g})$ thermally activated kaolinites ${ }^{(23-25)}$ and palygorskite-sepiolite ${ }^{26}$; (h) thermally activated bauxites ${ }^{27}$ (crystalline aluminium hydroxides).

The following classes group the methods to enhance or to activate the properties of a natural clay or clay mineral for several industrial uses ${ }^{28}$ :

(a) Physical - alteration of particle size (specific surface area) mechanically.

(b) Thermal - alteration of chemical composition and/or crystalline structure by the effect of temperature.

(c) Chemical - This is usually limited to ionic exchange: therefore, it does not include massive chemical destruction of the clay mineral structure.

(d) Pillaring -This may be regarded as using chemical and physical restructuring of the clay mineral structure to increase capacity for adsorption or to make spaces that encourage adsorption of specific ions (see Figure 1).

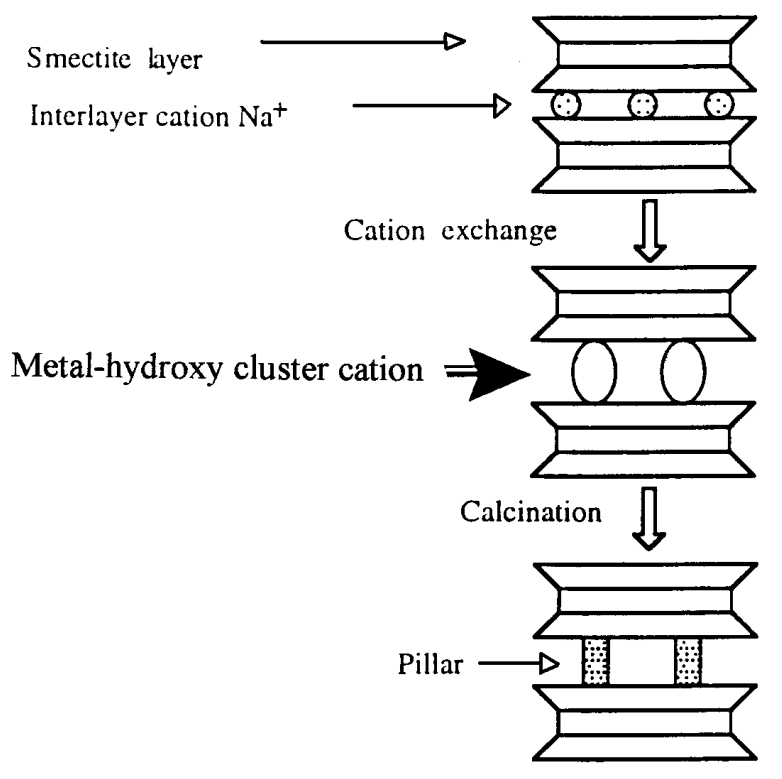

Figure 1. Schematic diagram for the preparation of pillared clay minerals (adapted from Moore and Reynods ${ }^{29}$ ).

\section{Other Types of Activation of Bentonites and of Different Minerals}

The chemical reaction of inorganic cation exchange of smectites may be considered an activation of the clays. So, the "synthetic" sodium bentonite, industrially processed by the reaction between polycationic-bentonite and sodium carbonate, is called in Germany "soda activated bentonite"(30-32). By analogy, other intercalated compounds of smectites, many of them with industrial application, such as quaternary ammonium ${ }^{(17,33)}$ and polyhydroximetal cations ${ }^{34}$, with polar and neutral organic molecules and the pillared smectites may also be considered as activated smectites or bentonites.

The thermal dehydroxilation is the chemical reaction represented by the equation: $2 \mathrm{OH}^{-}=\mathrm{H}_{2} \mathrm{O}(\mathrm{g})+\mathrm{O}^{2-}$. The solid produced is crystalline, but with defects; it is, usually, called an active solid ${ }^{8}$. Bauxites, kaolinite, halloysite, palygorskitesepiolite and vermiculite clays are usually thermally activated; the industrial product from bauxite is named "activated bauxite"; from kaolinite/halloysite is puozolan and from vermiculite is exfoliated vermiculite. In this paper, only the acid activation of smectites or bentonites will be considered. 


\section{NATURE OF THE ACID ACTIVATION OF NON-SWELLING-SMECTITES}

\section{Crystal Structure of the Smectite Clay Minerals ${ }^{35}$}

The clay minerals of the smectite group (previously called montmorillonite group) are composed of layers (called 2:1 layers) made up of two silica tetrahedral sheets with a central alumina octahedral sheet (Figure 2). Common oxygen atoms bind these sheets. The layers are continuous in the $a$ and the $b$ axis directions and are stacked one above the other in the $c$ direction, with the degree of order depending on the kind of smectite clay mineral. There may be moderately isomorphic substitutions varying on the kind of smectite clay mineral, for example, $\mathrm{Al}^{3+}$ for $\mathrm{Si}^{4+}$ in the tetrahedral sheets and $\mathrm{Mg}^{2+}$ for $\mathrm{Al}^{3+}$ in the octahedral sheets. Due to these substitutions the 2:1 layers are not electrically neutral (they have a negative charge), with a deficiency of about 0.66 monovalent cations per unit cell. That negative charge is balanced by interlayer exchangeable cations. That is the origin of the cation exchange capacity of the smectitic clay minerals.
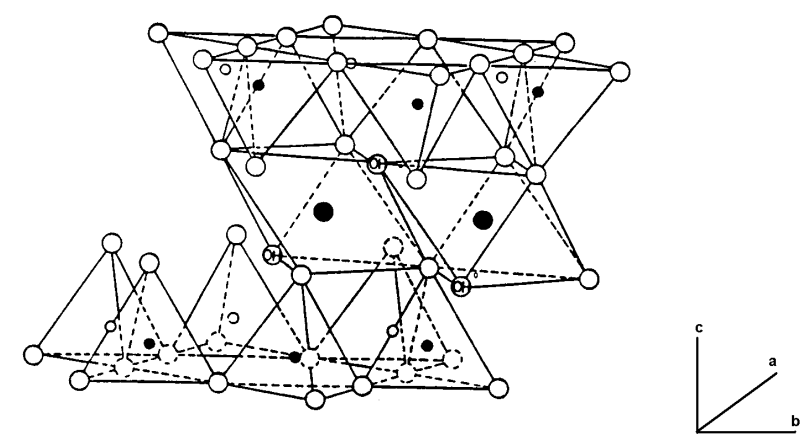

$\mathrm{nH}_{2} \mathrm{O}$, exchangeable cations

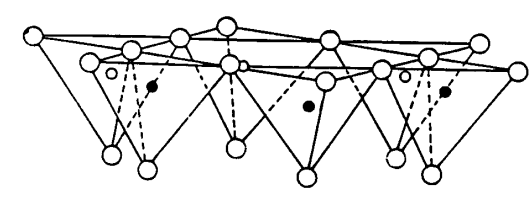

\footnotetext{
Oxygens 아 Hydroxyls Aluminum, iron, magnesium

- and 0 Silicon, occasionally aluminum
}

Figure 2. Schematic diagram of the structure of smectites (adapted from Grim $^{10}$ )

\section{The Importance of the Interlayer Exchangeable Cations ${ }^{36}$}

The Cation Exchange Capacity -CEC- and the Exchangeable Cations -EC- are important properties of the smectite clays and have great influence on their technological applications because they are fundamental control factors of the physical and chemical properties of the smectite clay minerals. There are two kinds of industrial bentonites: a) water swelling bentonites, with sodium as the main exchangeable cation and b) non water swelling bentonites, with calcium and/or magnesium as the main exchangeable cation. The swelling bentonites give highly thixotropic viscosity to water-clay dispersions at low clay concentrations. The non-swelling bentonites do not have that high thixotropy property and are floculated (precipitated) in water. The acid activation of smectitic clays is usually made on no-swelling smectites. There is no direct evidence that the swelling bentonites do not furnish bleaching clays, but they may present processing difficulties (as high viscosity dispersions, which difficult mass transport) on the activation with acid 37 .

\section{The Effect of the Acid Treatments on the Crystal Structure of the Smectites}

A number of characteristics determines the efficiency of a material as a bleaching earth. These properties are: adsorption capacity, acid properties, catalytic properties, ion exchange capacity and particle and pore size distributions. The acid treatment, besides leaching cations from octahedral and tetrahedral sheets, dissolves impurities such as calcite and replaces the exchangeable cations with hydrogen ions. The acid treatment also opens the edges of the platelets and as a consequence of all these changes, the surface area and the pore diameters increase. Usually $80 \%$ or more of the available surface area correspond to pores with diameters ranging from 2.0-6.0 nm, and the surface area can be increased with acid treatment to $200-400 \mathrm{~m}^{2} / \mathrm{g}$, although optimum bleaching results are generally obtained below this maximum.

Models of the acid attack on Ca-smectite and of the final structure/texture of the acid activated smectite were proposed by Thomas et $\mathrm{al}^{38}$ and by Taylor and Jenkins ${ }^{14}$. According to Lagaly ${ }^{31}$, the acid activated smectite is X-ray amorphous, but highly disordered tetrahedral layers still persist which are no longer lying parallel to each other (Figure 3 shows powder XRD patterns of some commercial acid activated bentonites). Adsorption of organic compounds can cause a certain parallel orientation of the layers; it is also called a "degraded bentonite" ". Dombrowsky and Henderson $^{39}$, from Engelhard, gave the following list of the changes that the smectite crystal suffers after the acid activation: (a) the edges of the crystal are opened and the $\mathrm{Al}^{3+}$ and $\mathrm{Mg}^{2+}$ cations of the octahedral sheet (from the 2:1 layers) are exposed to the acid and become soluble; (b) the surface pore diameter expands; (c) the "degree of crystallinity" of the clay mineral, as tentatively evaluated by the peak intensity and the width of the (001) peak is reduced; (d) the specific surface area of the smectite increases to a maximum, then it is reduced by additional treatment.

Therefore, the following facts are experimentally well established $\left(\right.$ Christidis $^{40}$, Ackermann $^{41}$, Winer ${ }^{42}$; Novak and Greggor ${ }^{13}$, Grim $^{10}$; Taylor and Jenkins ${ }^{14}$, Dombrowsky and Henderson ${ }^{39}$ ) for the products of the acid $\left(\mathrm{HCl}\right.$ or $\left.\mathrm{H}_{2} \mathrm{SO}_{4}\right)$ activation of a $\mathrm{Ca} / \mathrm{Mg}$-smectite: (a) as the intensity of the acid treatment is increased, the decolorizing ability for a given oil or fat increases up to an optimum value, but with further treatment there is a decline in that ability; (b) as the intensity of the acid treatment is increased, the specific surface area measured by $\mathrm{N}_{2}$ adsorption (BET method) ${ }^{43}$ increases up to a maximum ${ }^{44}$ value, which decreases with further treatment; (c) the optimum decolorizing ability of an activated smectite (for a given set of activating conditions) may or may not coincide with its maximum value of the surface area attained under those conditions (see Figure 4); (d) acid activated clays with good decolorizing ability have specific surface areas larger than $120 \mathrm{~m}^{2} / \mathrm{g}$; (e) the smectite structure is not completely destroyed either at the optimum decolorizing value or at the maximum surface area value; (f) the evaluation of an activated clay is determined by a comparative test of its decolorizing power against a proved effective commercial activated clay; $(\mathrm{g})$ the pore size ${ }^{*}$ distribution of an acid activated clay is also a very important property for industrial bleaching of oils. This property, known as mesoporosity, can be measured by the mercury porosimeter. The microporosity can be calculated in more sophisticated equipment for surface area measurement using low temperature $\mathrm{N}_{2}$ adsorption; also, high values of the constant $\mathrm{C}$ calculated in the BET equation are related to low values of the microporosity of the clay ${ }^{46}$. Valenzuela Díaz et $\mathrm{al}^{47,48}$ studied the effect of some physical properties of the original bentonite on the porosity of acid-activated smectites from Campina Grande, PB.

* According to IUAC ${ }^{45}$ pores are classified by their sizes: (a) pores which exceed $50 \mathrm{~nm}(0.05 \mathrm{~mm})$ are called macropores, (b) between $2 \mathrm{~nm}$ and $50 \mathrm{~nm}$ are called mesopores and (c) under $2 \mathrm{~nm}$ are called micropores. 


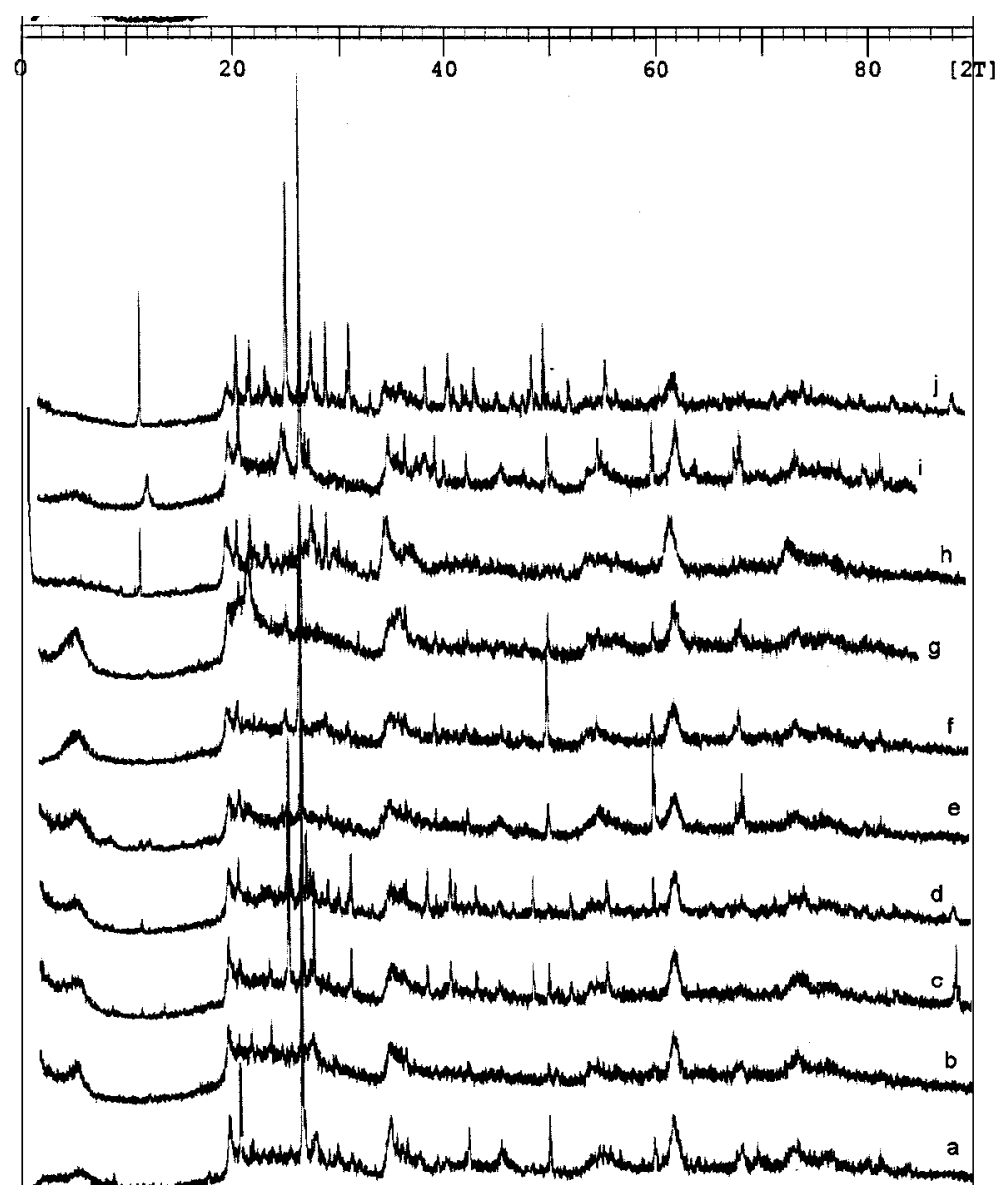

Figure 3. Powder DRX patterns of commercial acid activated bentonites: a) Tonsil Otimum 210 FF; b) Tonsil Supreme; c) Filtrol 105; d) Filtrol 160; e) Fulmont RP; f) Fulmont Premiere; g) Alclor Tipo 2; h) Tonsil (México); i) Alclor Tipo 1; j) Tonsil Optimum. The patterns were measured on Philips X'PERT MPD diffractometer using $\mathrm{Cu} K$ radiation $(40 \mathrm{kV}-40 \mathrm{~mA}$; scan speed $0.020 \mathrm{\Theta} / \mathrm{s}$ and time per step $2 \mathrm{~s})$. The $d_{001}$ peaks at about $5.4^{\circ} 2 \Theta\left(d_{001}=16.4 \AA\right)$, whose intensities and widths could be used to evaluate the "degree of crystallinity" varied from almost imperceptible peaks (Tonsil Optimum sample) to good defined peaks (Alclor Tipo 2 sample). The sample Tonsil México and Tonsil Optimum have a peak at 11.6 ${ }^{\circ}$ $2 \Theta$, (possibly gypsum) and the sample Alclor Tipo 1 at $12.3^{\circ} 2 \Theta$ (possibly kaolinite). All the samples have peaks at $25.5^{\circ} 2 \Theta($ quartz).

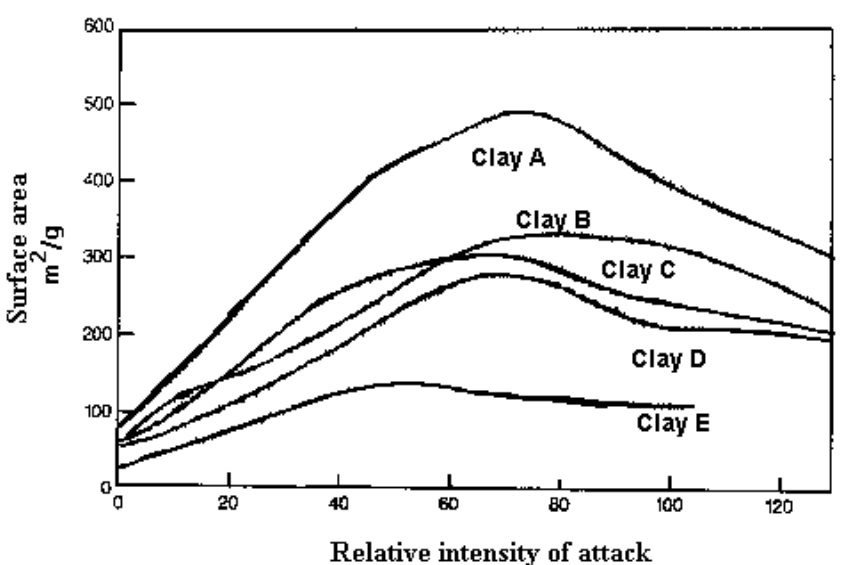

(a)

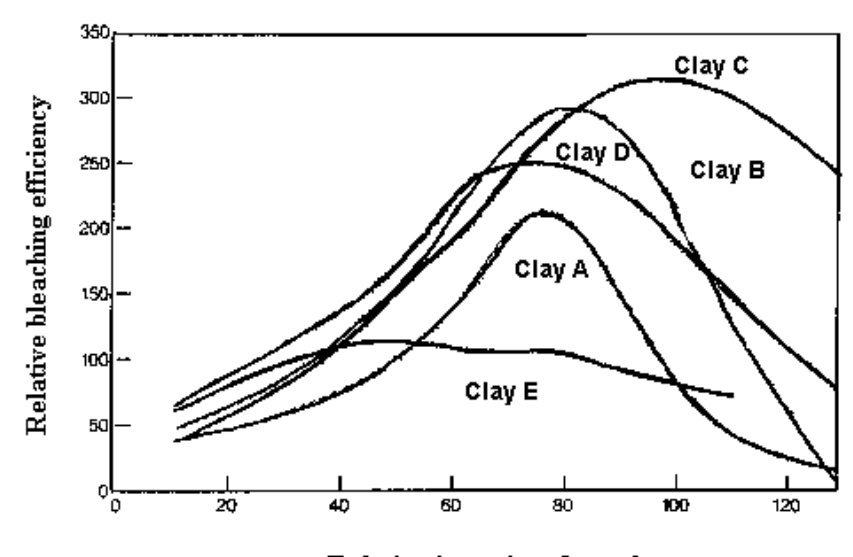

Relative intensity of attack

(b)

Figure 4. a) Surface area of some bleaching clays versus intensity of attack, b) bleaching efficiency of those clays versus intensity of attack. Observe that the maximum of surface area does not necessarily correspond to the maximum for bleaching efficiency. Adapted from Engelhard 52.

The most important variables affecting the properties of the acid activated smectites are: temperature, treating time, and dry acid/clay ratio. Other variables are: acid concentration, nature of the inorganic acid $\left(\mathrm{HCl}\right.$ or $\left.\mathrm{H}_{2} \mathrm{SO}_{4}\right)$, initial humidity or moisture content $(12 \%-18 \%)$, particle size of the smectite washing procedure, and drying temperature of the activated clay $\left(110^{\circ} \mathrm{C}\right)^{(15,41,49-51)}$.

Dombrowsky and Henderson ${ }^{39}$, from Engelhard, summarized the properties and applications of acid activated non-swelling Ca-smectites: they have an exceptional capacity to adsorb 
impurities and are used principally for the purification and modification of organic chemicals; they are used as catalysts because of their large pore size and surface acidity that offers unique properties in strong acid-catalysed reactions. These features allow a large variety of applications, the most traditional being: fat and oil bleaching or decolorizing; mineral oil bleaching in contact/filtration processes; fixed bed adsorbents and many other catalytic applications. Since the decolorizing action is very specific, the companies producing activated clays and fuller's earths publish data sheets in which they list the types of commercial clays that they offer and for which oils, fats and waxes they are recommended for industrial decolorization (Fuller's Earth Union ${ }^{53}$, Süd-Chemie ${ }^{(54,55)}$,

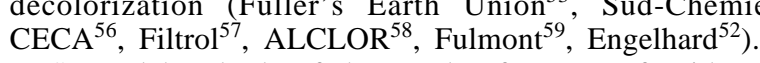

Several hundreds of thousands of tonnes of acid activated clays are used every year for filtering and decolorizing vegetable and animal oils and fats. For the industrial processed acid activated bentonite more evaluation tests are needed for each type of oil, glyceride or hydrocarbons, solvents, and chemicals treated ${ }^{4}$.

Most vegetable, animal, and fish oils require refining to remove impurities such as phosphatides, gums, trace metals and free fatty acids which may produce oxidation products leading to degeneration and short shelf life of the final product. Bleaching clays adsorb many of these products and also reduce the red, yellow, and green coloration produced by compounds such as carotene, caroteinoids, xanthophyll, and chlorophyll to more acceptable levels.

In vegetable oil refining, the principal goal of the use of bleaching clays is the elimination of a series of contaminants, that can be grouped in function of their nature, into: primary, secondary, and terciary ${ }^{60}$. The primary contaminants are oil soluble components originated from vegetal organisms: proteins, sterols, tocoferols, hydrocarbons, and natural pigments (chlorophyll, carotenoids-carotene, lutein, gossipol, or xanthophyll). The secondary contaminants are organic compounds formed inside the oil seeds by chemical degradation during their storage: free fatty acids, peroxides, ketones, aldehydes, pigments, and nonhydrolysable phosphatides. The tertiary contaminants are chemical compounds left or aggregated during the growth, development and processing of the oil seed; those coming from the deterioration of the equipment used in the process or by thermal degradation, solvents, biocides, free fatty acids, soaps, heavy metals (as $\mathrm{Fe}^{3+}$ and $\mathrm{Cu}^{2+}$ ), phosphoric and citric acids, and others. Degumming reduces $70 \%$ to $80 \%$ of the phosphatides by $1 \%-3 \%$ water addition to the oil heated at $60{ }^{\circ} \mathrm{C}-70{ }^{\circ} \mathrm{C}$ for $20-30$ minutes. As an example, soybean oil contains $1 \%-3 \%$ of phospholipids. Reducing phospholipids to acceptable low levels is a necessary requirement before hydrogenation or deodorization.

Besides a good decolorizing ability, an acid activated clay, in order to be an industrially/commercially adequate product, must also satisfy a set of requirements, which are needed to be evaluated experimentally. These requirements are listed in detail by Souza Santos $^{61}$ and examples are given by Taylor and Jenkins ${ }^{14}$.

Recently, it has been shown that the acid activation of sodium-smectites produces acid activated clays with good decolorizing ability, in contrast to the traditional idea that the acid activation would decompose completely the Na-smectite into silicic acid ${ }^{(62,63)}$. Besides the acid activation on $\mathrm{Ca}$ smectites, the acid activation can be conducted on organic cation exchanged-smectites in order to produce activated clays with specific or tailored properties; an example is the acid activation of quaternary ammonium smectites for catalyst production (an example: alpha-pinene to camphene ${ }^{64}$; it compares favourably with the activation of pillared clays $\left.{ }^{(65,66)}\right)$.

Adsorbent clays have been traditionally used to clarify wine, beer and cider. The so-called Spanish earth, composed mainly by an attapulgite, from the area of Jerez de la Frontera was used for centuries for the clarification of wine in Spain. The most used absorbent clay for wine clarification is bentonite. It is added in quantities ranging from 1-2 per 1000 to remove proteins, colloidal particles and to reduce acidity. Bentonite is particularly efficient in wines which are difficult to clarify such as port and moscatel ${ }^{4}$.

\section{LABORATORY METHODS FOR THE ACID ACTIVATION OF BENTONITES}

The activation tests conducted on Brazilian clays in our Laboratory were conducted according the following procedures.

\section{Sample Preparation and Characterization}

The smectite clay was dried at $60{ }^{\circ} \mathrm{C}$ to humidity between 12 $\%$ and $18 \%$. Then it was ground and passed in USS sieve $\mathrm{n}^{\circ}$ $200(74 \mathrm{~mm})$ and examined by powder X-ray diffraction to confirm the presence of the smectite group by the conventional procedures (ethylene glycol; glycerol on the Mg-form; $500{ }^{\circ} \mathrm{C}$ heating), described by Brown ${ }^{67}$, and used to differentiate clay minerals of the $14 \AA$ group, for example smectites from vermiculites. Foster's swelling in water was made to check for non-swelling $\mathrm{Ca} / \mathrm{Mg}$-smectite ${ }^{68}$. Chemical analysis, CEC and EC determinations were made when required for other purposes.

\section{Preliminary Activation Test}

This test is conducted when the amount of sample is small (100 g-200 g: piece of a drilling core) or a first evaluation was required. The following procedure is used, based on papers by Ackermann ${ }^{41}$ and Winer ${ }^{42}$ : 100 grams of the ground clay (dry basis, $110^{\circ} \mathrm{C}$ ) are placed in a 1 litre, 3-neck round bottom flask heated by an electrical mantle; $400 \mathrm{~mL}$ of $1: 1(\mathrm{v} / \mathrm{v})$ hydrochloric acid $\left(\mathrm{d}=1,16 \mathrm{~g} / \mathrm{mL} ; 32 \mathrm{~g} \mathrm{HCl} / 100 \mathrm{~mL} \cong 9 \mathrm{~mol} * \mathrm{dm}^{-3}\right)$ solution are added; so that the $\mathrm{HCl}$ concentration is $16 \%(\mathrm{w} / \mathrm{v})$ or 4.5 mol $* \mathrm{dm}^{-3}$ and the dry acid/clay ratio $(\mathrm{w} / \mathrm{w})$ is 0.64 . Thermometer, stirrer and reflux condenser are attached to the flask; the temperature is maintained at $80{ }^{\circ} \mathrm{C}$ for 3 hours with constant stirring. While hot, the clay suspension is transferred to a two litre beaker and washed by decantation with distilled water for at least 5 times until it is $\mathrm{Cl}^{-}$and/or $\mathrm{Fe}^{3+}$ free $(\mathrm{pH}=$ $3,5-4,0)$. The acid activated clay is filtered in a Büchner funnel, dried at $110{ }^{\circ} \mathrm{C}$ and reground to pass $\mathrm{n}^{\circ} 200$ sieve $(74 \mathrm{~mm})$ for the decolorization test. This test, being conducted under relatively moderate conditions of activation, generally does not lead to the optimum value of decolorizing power (or the maximum value of specific surface area), which can be reached by more intense treating conditions (higher temperature, longer times of activation and higher acid ratios, even using higher acid concentrations). However, the decolorization test being conducted according the AOCS method ${ }^{69}$, using $6.0 \%$ of activated clay (the industrial contact process for vegetable oils uses 0.5 to $3.0 \%{ }^{70}$ ), usually gives a good indication if the acid activation is developing or not a decolorizing ability in the clay. Such information helps to determine if further acid activation studies are worthy or not for that clay.

\section{Factorial Model of Two Levels}

If we have $1.5 / 2.0 \mathrm{~kg}$ of clay and at least ten days to conduct all the evaluation, an alternative option to prepare a small number of samples of activated clay to be tested for decolorizing ability is to conduct the activation procedures according a statistical test named factorial model of two levels; it has: (a) two levels, a maximum and a minimum; (b) three variables: temperature; time of treating; and acid concentration or acid/clay ratio ${ }^{(71,72)}$. So, $2^{3}=8$ samples of activated clay will be prepared. Constant: weight of clay; final volume or the concentration of the acid solution; nature of the acid. 
Examples: (A) $60{ }^{\circ} \mathrm{C}$ and $80{ }^{\circ} \mathrm{C}$; $1 / 2$ and 3 hours; $7.5 \%$ (0.75 mol $\left.* \mathrm{dm}^{-3}\right)$ and $15 \%\left(1.5 \mathrm{~mol} * \mathrm{dm}^{-3}\right) \mathrm{H}_{2} \mathrm{SO}_{4}$ concentration; weight of bentonite: $50.0 \mathrm{~g}$ (dry basis; $12 \%-18 \%$ humidity); and final volume $=400 \mathrm{~mL}$. (B) Another example of a $2^{3}$ test: weight of clay: $100 \mathrm{~g}$; hydrochloric acid $1: 1(16 \% ; 16 \mathrm{~g} \mathrm{HCl} /$ $100 \mathrm{~mL}$; $\left.4.5 \mathrm{~mol} * \mathrm{dm}^{-3}\right)$; temperatures: $50{ }^{\circ} \mathrm{C}$ and $90{ }^{\circ} \mathrm{C}$; time: $2 \mathrm{~h}$ and $6 \mathrm{~h}$;; volume of acid: $150 \mathrm{~mL}$ and $250 \mathrm{~mL}$. The verification of the effect of these variables is made by a decolorizing test of an oil in comparison with a well-known commercial acid activated clay (Tonsil; Filtrol; Engelhard), according to a standard procedure like from AOCS. That $2^{3}$ test generally may indicate which are the values of these tree variables that must be considered together to obtain the highest bleaching values of the oil from the acid treated clay samples. However, it must be noted in the examples that the two levels, smaller and higher, of each of tree variables is arbitrary and is many times chosen either from previous experience or from literature on other smectites. Therefore, the maximum acid bleaching activity of a given clay may not be obtained by the use of only one test with $3 * 2$ values of the most important activation variables.

\section{Decolorizing vs. Treating Time}

Now, the following standard activation test is used in our Laboratory: (a) constant weight of clay (100 g); (b) constant volume of the acid solution $(400 \mathrm{~mL})$; (c) acid used: $\mathrm{HCl}$; $\mathrm{d}=1.16 \mathrm{~g} / \mathrm{mL} ; 32 \%(\mathrm{w} / \mathrm{v}) ;$ (d) constant dry acid/clay weight ratio $=1,0(25 \% ; 330 \mathrm{~mL} \mathrm{HCl}$ in $400 \mathrm{~mL}$ as the final volume); (e) constant temperature $=90{ }^{\circ} \mathrm{C}$. Variable tested: treatment time: $1 \mathrm{~h} ; 2 \mathrm{~h}, \ldots 8 \mathrm{~h} ; 9 \mathrm{~h} ; 10 \mathrm{~h}$; (total number of samples: 10). Minimum weight of clay: $2 \mathrm{~kg}$; period needed to evaluate the clay: two weeks.

This activation procedure gives the value of the decolorizing power of the activated clay as a function of the treatment time at $90{ }^{\circ} \mathrm{C}$ for a 10 hour period. In general, the curve shows a maximum value (optimum decolorizing power, see Figure 4 for examples of bleaching efficiency versus intensity of attack for various bleaching clays) for a given color which may be compared with the one obtained from the standard commercial activated clay, under the same experimental conditions. If the values of the decolorizing power are similar, then the BET nitrogen surface areas of the samples, near those optimum values, are measured to check if the minimum of $120 \mathrm{~m}^{2} / \mathrm{g}$ is reached and to verify if the sample with the greater surface area has the optimum decolorizing power. Also, X-ray powder diffraction is conducted in these samples to check if the smectite structure is not completely destroyed and the pore sizes are calculated, if the equipment for BET can supply data for that.

The amounts of activated clays prepared by the activation procedure described above are enough to test 4 or 5 different types or samples of oils or fats or waxes.

The criteria for choice, either sulfuric or hydrochloric acid or even nitric acid in the industrial process, is of economical nature; therefore, it must not be considered as a variable in a bench scale study. It is recommended that the research group uses, for all studied clays, the same acid (or both acids) in order to compare the experimental results for different clays.

It must be pointed out that the initial acid concentration is frequently used as a variable in several published papers. However, it must always be kept in mind the fact that the acid concentration, whatever its initial value, will always decrease along the time of treatment due to the attack and dissolution of the octahedral layer. Besides, since higher temperatures will increase the rate of that reaction, temperature is sometimes used as a variable for the activation; but the real "activation" variable that should be considered in the control process, for all initial acid concentrations and temperatures of reaction, is the time of treatment. Based on this idea the following example is presented:
TYPICAL ACTIVATION TEST OF A BENTONITE ${ }^{(73,74)}$ (From Palmeira District - Lages County - State of Santa Catarina)

1) Clay size $=$ finer than $\mathrm{n}^{\circ} 200 \mathrm{ABNT}$ sieve $\left.(74 \mathrm{~mm}) ; 2\right)$ Humidity $\left.\left(105{ }^{\circ} \mathrm{C} / 110{ }^{\circ} \mathrm{C}\right)=14 \% \mathrm{w} / \mathrm{w} ; 3\right)$ Weight of the dry clay $=100 \mathrm{~g} ; 4)$ Acid used $=\mathrm{HCl}(\mathrm{d}=1,16 \mathrm{~g} / \mathrm{mL})=$ $32 \mathrm{~g} \mathrm{HCl} / 100 \mathrm{~mL}$; 5) Ratio of weight clay : volume $(\mathrm{mL})$ of acid $=1: 4=(100: 400) ; 6)$ Temperature $=90^{\circ} \mathrm{C} \pm 2{ }^{\circ} \mathrm{C}$; 7) Treatment time $=3$ hours; 8) Variable: $\mathrm{HCl}$ concentration $=5 \%, 10 \%$ to $30 \%(\mathrm{~g} / 100 \mathrm{~mL})$.

Number of samples to be tested: 6 activated bentonites plus blank (non-treated bentonite) plus sample of commercial acid activated bentonite (Tonsil Optimum NFF) as reference.

Filtered and water washed $\left(\mathrm{pH}=3,5 / 4,0-\mathrm{Cl}^{-}\right.$and/or $\mathrm{Fe}^{3+}$ free), dried $105{ }^{\circ} \mathrm{C} / 110{ }^{\circ} \mathrm{C}$-reground finer than $\mathrm{n}^{\circ} 200$ sieve. The activated clay is ready for tests of characterization and evaluation of decolorizing power. The next step is to test the decolorizing power for vegetable oils produced in the State of Santa Catarina. Only vegetable oils will be studied since there is no production of lubricating oils in that State.

TYPICAL DECOLORIZATION TEST OF A VEGETABLE OIL - SOYBEAN BY ACID ACTIVATED BENTONITE (Palmeira, SC) $^{73}$

\section{Experimental Conditions:}

Spectrophotometer model 1051 -CACIEN; (b) Wavelength used $=440 \mathrm{~nm}$; (c) Soybean oil absorbance (diluted 1.4x in n-hexane) = 0,904; (d) Reference activated bentonite:Tonsil Optimum NFF; (e) Percentages tested-clay:oil ( $\mathrm{w} / \mathrm{w}=0.5 \% ; 1.0 \% ; 1.5 \% ; 2.0 \%)$; (f) Temperature of test $=90{ }^{\circ} \mathrm{C} \pm 2{ }^{\circ} \mathrm{C}$; contact time $=30$ minutes. The experimental conditions were chosen based on the AOCS bleaching test $^{69}$, using temperature and clay/oil ratios similar to those used by the Santa Catarina's Company "Ceval" for the bleaching of soybean oil. The soybean oil is the same used by "Ceval" Company. The results obtained are shown in Table 1.

Table 1. Absorbances of the decolorized "Ceval" soybean oil.

\begin{tabular}{ccccc}
\hline Acid & \multicolumn{4}{c}{ Clay (\%) } \\
\cline { 2 - 5 } concentration (\%) & 0.5 & 1.0 & 1.5 & 2.0 \\
\hline 5 & $0.615^{*}$ & $0.418^{*}$ & 1.854 & 1.678 \\
10 & $0.511^{*}$ & $0.317^{*}$ & 0.508 & 0.318 \\
15 & 0.641 & 0.384 & 0.291 & 0.251 \\
20 & 0.787 & 0.410 & 0.300 & 0.218 \\
25 & 0.794 & 0.419 & 0.351 & 0.261 \\
30 & 0.801 & 0.512 & 0.766 & 0.230 \\
$\begin{array}{c}\text { Reference } \\
\text { activated } \\
\text { clay }\end{array}$ & 1.248 & 0.308 & 0.232 & 0.222 \\
\hline
\end{tabular}

(*) Oil diluted $3 \mathrm{x}$ in $\mathrm{n}$-hexane

\section{CONCLUSIONS FOR THE BLEACHING TEST}

The smaller the value of the absorbance, the larger or better the decolorizing power of the acid activated bentonite. The reference clay, used in the industrial process at $2.0 \%$ concentration, gives the same absorbance as the Palmeira bentonite at $2.0 \%$ activated by $20 \% \mathrm{HCl}$.

\section{SOME RESULTS OF STUDIES ON ACTIVATION OF BRAZILIAN SMECTITES}

Bentonites and also some fuller's earths exist in several places of Brazil; acid activation of the bentonites and oil decolorization 
studies with these clays have been made and several publications exist. The studies on Brazilian clays, especially fuller's earth, for decolorization of oils and fats published until 1959 were reviewed by Souza Santos ${ }^{75}$. The results which are going to be presented are organized by the State where the clay deposit is, starting from the northeastern region.

\section{Northeast}

The $\mathrm{Ca} / \mathrm{Mg}$ bentonite deposits of Boa Vista district, Campina Grande County, State of Paraíba may be activated with 5 mol $* \mathrm{dm}^{-3}$ of $\mathrm{H}_{2} \mathrm{SO}_{4}$ at $80{ }^{\circ} \mathrm{C}$ for 7 hours and have good decolorizing power for castor, soybean and cotton oils ${ }^{(49,76)}$. These bentonites were used later as raw material for the industrial production of $\mathrm{HCl}$ activated clay by ALCLOR in Camaçari, Bahia and in Marechal Deodoro, Alagoas 3 .

Ferreira $^{76}$ studied the activation in the same conditions, of a Ca-smectite, from Riachão Farm, Equador County, State of Rio Grande do Norte; the activated clay had very good decolorizing power for castor, soybean and cottonseed oils produced in the region.

Baraúna $^{77}$ characterised the $\mathrm{Ca} / \mathrm{Mg}$ bentonite beds that overlay the gypsum deposits of the Santana Formation in the State of Pernambuco. The bentonites from Lagoa de Dentro, Araripina, $\mathrm{PE}$ were activated by $\mathrm{HCl}$ in a $2^{3}$ factorial planning, as described before. The decolorization power was evaluated for 8 samples and compared to Tonsil (from Tonsil Mexicana S.A., Puebla, México) using local soybean oil, with very good results for the higher levels of temperature and treating time ${ }^{(71,72,78)}$. A similar $2^{3}$ factorial planning study was conducted by Palza, at the Chemical Institute of the University of São Paulo, on a $\mathrm{Ca} /$ $\mathrm{Mg}$ smectite from Chile (Sociedade Minera Condor) with $\mathrm{H}_{2} \mathrm{SO}_{4}$, with good results on decolorizing Brazilian soybean oil ${ }^{79}$. The green Ca-smectite from the Vitória da Conquista County, State of Bahia, activated by $\mathrm{HCl} 12 \mathrm{~mol} * \mathrm{dm}^{-3}$ at $80{ }^{\circ} \mathrm{C}$ for 6 hours is a good decolorizing agent for castor oil ${ }^{80}$.

\section{Minas Gerais and São Paulo}

The large calcite deposit in Ponte Alta County, State of Minas Gerais contains a thick bed of light-grey Ca-montmorillonite; $\mathrm{H}_{2} \mathrm{SO}_{4}$ activation produces excellent bleaching clay for cottonseed, castor soybean and lubricating oils ${ }^{(81,82)}$. The Counties of Sacramento and Carmo do Paranaíba, Minas Gerais have large deposits of deep green nontronitic smectites; $\mathrm{H}_{2} \mathrm{SO}_{4}$ activation of these nontronites produces very good bleaching clays for decolorizing cottonseed and soybean oils and they are fairly good bleaching agents for lubricating oils ${ }^{(81,82)}$.

The valley of the Paraiba river (Taubaté Basin) has an oil shale deposits in the Counties of Taubaté and Pindamonhangaba, in the State of São Paulo. The green sedimentary clays associated to the shale contain smectites, illite and kaolinite. Several companies produce these clays as an excellent fuller's earth for decolorizing vegetable oils: Mineração Santa Fé (Tremembé); Aligra and Argos (Taubaté) and Eucatex (Pindamonhangaba). The $\mathrm{H}_{2} \mathrm{SO}_{4}$ activation of the fuller's earth produces a good bleaching clay for cottonseed, castor and soybean oils and it is fairly good bleaching agent for lubricating oils. A new smectite deposit was discovered recently in São Domingos do Pinhão, near Pindamonhangaba: it is a smectite-rich clay; and a factory was constructed to produce the acid activated smectite named Argitex for the decolorization of oils ${ }^{60}$. This company today is named "Fulmont Argilas Ativadas Ltda" and is a joint venture between Bentonit União (Campina Grande) and Eucatex Mineral (São Paulo); the factory produces the bleaching clays (activated and fuller's earth) named Fulmont-Argite ${ }^{59}$.

In the region of Jundiaí County and vicinity, SP, large blocks of apple-green nontronitic smectite are found formed from the weathering of amphibolic dykes ${ }^{83} \cdot \mathrm{H}_{2} \mathrm{SO}_{4}$ activation of these clays produces bleaching clays which are good decolorizing agents for cottonseed, castor, soybean and lubricating oils ${ }^{(81,82)}$.

The Franca County, SP, is the second diamond producer in Brazil; large deposits of smectitic clays exist in three areas: Restinga (Auxiliadora Farm); Pedregulho and Serra da Faquinha ${ }^{84}$. The clays, activated by $\mathrm{H}_{2} \mathrm{SO}_{4}$, give excellent bleaching materials for cottonseed, soybean, castor and lubricating oils ${ }^{(81,82)}$. These clays are under consideration for industrial production by Fulmont.

\section{Southern States}

The Paraná State has several deposits of smectitic clays in the Counties of Carlopolis; Siqueira Campos, Curitiba, Lapa, Campina Grande do Sul, Castro, Ponta Grossa (associated to the large talc deposits), Colombo and Tomazina ${ }^{(85-89)}$. Unfortunately, no published study of activation of these clays is known.

The Rio Grande do Sul State also has several deposits of smectitic clays ${ }^{90}$. However, the only study on $\mathrm{H}_{2} \mathrm{SO}_{4}$ activation of the smectitic clay from Arroio Bretanha, Jaguarão County was made by Figueiredo and Scarrone ${ }^{91}$ : the activated clay is a fairly good decolorizing agent for soybean oil.

Characterisation as smectites of clays from the Lages County, State of Santa Catarina was made by Souza Santos et al ${ }^{92}$. Preliminary studies on some technological properties of a green smectitic clay from the Palmeira District, Lages County were made and published by Schardong and Morgado ${ }^{93}$, Morgado e Moreira $^{94}$, Morgado et $\mathrm{al}^{95}$, Morgado ${ }^{96}$, Morgado e Souza Santos ${ }^{97}$. The dark-green iron-rich smectitic clay (from a 5 meters thick bed) has aluminium and potassium as the majority of the exchangeable cations. Its CEC value is $80 \mathrm{mEq} / 100 \mathrm{~g}$ of clay and the $\mathrm{N}_{2}$ BET surface area is $54 \mathrm{~m}^{2} / \mathrm{g}$. The acid activation was made with $\mathrm{HCl}$; the temperature: $90^{\circ} \mathrm{C}$. Treatment time; 3 hours; clay/acid ratio $=1: 4$ (constant) weight of clay $=100 \mathrm{~g} ;$ minus $\mathrm{n}^{\circ}$ 200 sieve; the acid concentrations (w/v) were $5 \%$ to $30 \%$ using $\mathrm{HCl}(\mathrm{d}=1.16 \mathrm{~g} / \mathrm{mL})$; oils tested: soybean; corn and sunflower at a temperature of $90{ }^{\circ} \mathrm{C}$ for 30 minutes. The best results were obtained for three oils with $20 \% \mathrm{HCl}$ concentration ${ }^{73}$. Studies are under course to optimize the treatment time.

\section{CONCLUSIONS}

Studies have shown that acid activation by $\mathrm{HCl}$ or $\mathrm{H}_{2} \mathrm{SO}_{4}$ of smectite clays from the States of Paraíba, Rio Grande do Norte, Pernambuco, Bahia, Minas Gerais, São Paulo, Santa Catarina and Rio Grande do Sul, Brazil produce good bleaching clays, comparable with some well known foreign commercial acid activated clays. The decolorizing power of these activated clays was shown to be efficient for the following vegetable oils: soybean, cottonseed, sunflower, corn, and castor produced in the regions of the bentonite deposits and some also for lubricating oils.

\section{ACKNOWLEDGEMENTS}

This work was supported by the FAPESP Project 1995/ 0544-0. Presented in part at the International Workshop of Activated Clays, La Plata, Argentina (1998).

\section{REFERENCES}

1. Ladoo, R. B.; Myers, W. M. In Non Metallic Minerals; McGraw-Hill; New York, 1953; p 233.

2. Robertson, R. H.; Fuller's Earth: A History of Calcium Montmorillonite; Volturna Press; Kent, 1986; p 2.

3. Araujo, M. A. S.; Telles, A. S.; Braz. J. Chem. Eng. 1995, 12,98 . 
4. Santarén, J.; Industrial Minerals 1993, 304, 35.

5. Cutler, I. B. In Ceramic Processing Before Firing; Onoda, G. Y.; Hench, L. L., Ed.; Wiley; New York, 1978; p 31.

6. Oberlander, R. K. In Appl. Industrial Catal.; Leach, B. C., Ed.; v 3; Academic Press; Orlando, Florida, 1984; p 66.

7. Goodboy, K. P.; Downing, J. C. In Alumina Chemicals; Hart, L. D., Ed.; American Ceramic Society; Westerville, Ohio, 1990, p 93.

8. Gregg, S. J. In Surface Phenomena in Chemistry and Biology; Danielli, J.; Pankhust, K. G. A.; Riddiford, A. C.; Ed.; Pergamon Press; London, 1958; p 195.

9. Grim, R. E.; Applied Clay Mineralogy; McGraw-Hill; New York, 1962; p 321.

10. Grim, R. E.; Clay Mineralogy; $2^{\text {nd }}$ ed.; McGraw-Hill; New York, 1968; p 464.

11. Van Olphen, H.; Fripiat, J. J.; Data Handbook for Clay Materials and Other Non-Metallic Materials; Pergamon Press; Oxford, 1979; p 212.

12. Lamar, R. S.; California J. Mines Geol. 1951, 49, 297.

13. Novak, J.; Gregor, M. In Proceed. Int. Clay Conf., Tokyo, 1969; Israel University Press; Jerusalem, 1969; v 1; p 851.

14. Taylor, D. R.; Jenkins, D. B.; Acid activated clay. In $S M E$ Fall Meeting, St. Louis, 1986, SME; St. Louis, 1986; Paper $n^{\circ} 86$, p 365 and Figure 3.

15. Souza-Santos, P.; Estudo tecnológico de argilas montmoriloníticas do Distrito de Boa Vista, Municipio de Campina Grande, Paraíba; Publication 862, IPT, Instituto de Pesquisas Tecnológicas do Estado de São Paulo; IPT; São Paulo, Brazil, 1976.

16. Dematte, C. L.; Cerâmica. 1980, 26, 353.

17. Valenzuela-Díaz, F. R.; Doctorate Thesis; Depto. de Eng. Química, EPUSP, Escola Politécnica da Universidade de São Paulo, São Paulo, Brazil, 1994.

18. Souza-Santos, P.; Ciência e Tecnologia de Argilas; $2^{\text {nd }}$ Ed., Editora Edgard Blücher; São Paulo, Brazil, 1992; v 2, Chap. 34.

19. Makinnon, I. R. D. In International Workshop of Activated Clays; La Plata, Argentina, 1998; p 55.

20. Souza-Santos, P.; Ciência e Tecnologia de Argilas; $2^{\text {nd }}$ Ed.; Editora Edgard Blücher, São Paulo, Brazil, 1992; v 2; Chap. 35

21. Luna, F. J., Schuchardt, U.; Quim. Nova 1999, 22, 104.

22. Pinnavaia, T. J.; Science 1983, 220, 365.

23. Gregg, S. J.; Stephens, M. J.; J. Chem. Soc. 1953, p 3951.

24. Souza-Santos, P.; Ciência e Tecnologia de Argilas; $2^{\text {nd }}$ Ed.; Editora Edgard Blücher; São Paulo, Brazil, 1992; v 2, p 426.

25. Milliken Jr, T. H.; Mills, G. A.; Oblad, A. G.; Faraday Discuss. Soc. 1950, 8, 279.

26. McCarter, W. S. W.; Krieger, K. A.; Heinemann, H.; Ind. Eng. Chem. 1950, 42, 529.

27. King, H. L.; Laughlin, C. D.; Gwin, H. M.; Oil and Gas J. 1944, 42, 236.

28. Churchman, G. J. In International Workshop of Activated Clays; La Plata, Argentina, 1998; p 9.

29. Moore, D. M.; Reynolds Jr, R. C.; X-Ray Diffraction and the Identification and Analysis of Clay Minerals; $2^{\text {nd }}$ ed.; Oxford University Press; Oxford, 1997.

30. Fahn, R.; Ber Deut. Keram. Ges. 1964, 41, 546.

31. Lagaly, G. In Clays Controlling the Environment; Churchman, G. D., Ed.; CSIRO Publishing; Melbourne, 1995 ; p 137.

32. PETROBRÁS; Ensaio de argila ativada para fluido de perfuração à base de argila doce; Norma N-1446e (método; emenda); Rio de Janeiro, Agosto de 1988.

33. Valenzuela-Díaz, F. R.; Vieira-Coelho, A. C.; Abreu, L. D. V. de; Souza-Santos, P. In Anais do $3^{\circ}$ Congresso Italo-Brasileiro de Engenharia de Minas, Verona, Itália, 1988; p 124.
34. Vieira-Coelho, A. C.; Ph.D. Thesis, Universié Catholique de Louvain; Louvain-la-Neuve, Belgium, 1991.

35. Souza-Santos, P.; Ciência e Tecnologia de Argilas; $2^{\text {nd }}$ ed.; Editora Edgard Blücher; São Paulo, 1989; v 1; p 66.

36. Souza-Santos, P.; Ciência e Tecnologia de Argilas; $2^{\text {nd }}$ ed.; Editora Edgard Blücher, São Paulo, 1989; v 1; Chap. 7.

37. Valenzuela-Díaz, F. R.; Souza-Santos, P.; Cerâmica 1991, $37,70$.

38. Thomas, C. L.; Hickey, J.; Stecker, G.; Ind. Eng. Chem. 1950, 42, 866

39. Dombrowsky, T.; Henderson, J. In: Clays for our Future; Book of Abstracts; Carleton University; Ottawa, 1997; p A23.

40. Christidis, G. E.; Scott, P. W.; Dunham, A. C.; Appl. Clay Sci. 1997, 12, 329.

41. Ackermann, A.; Chimie et Industrie 1949, 61, 29.

42. Winer, A. A.; Acid activation of Saskatchewan bentonites; Report of Investigations $n^{\circ} 4$; Dept. of Mineral Resources; Province of Saskatchwan, Canada, 1954; p 14.

43. Lowell, S.; Shields, J. E.; Powder Surface Area and Porosity; Third ed.; Chapman \& Hall; London, 1991.

44. Mendioroz, S.; Pajares, J. A.; Benito, I.; Pesquera, C.; González, F.; Blanco, C.; Langmuir 1987, 3, 676.

45. Sing, K. S. W.; Everett, D. H.; Haul, R. A. W.; Moscou, L.; Pierotti, R. A.; Rouquenol, J.; Siemieniewska, T.; Pure Appl. Chem. 1985, 57, 603.

46. Gregg, S. J.; Sing, K. S. W.; Adsorption, Surface Area and Porosity; Academic Press; London, 1967.

47. Valenzuela-Díaz, F. R.; Souza-Santos, P.; Cerâmica 1991, $35,70$.

48. Valenzuela-Díaz, F. R.; Souza-Santos, P.; Mendioroz, S. In Anais do $10^{\circ}$ Congresso Brasileiro de Engenharia Química; São Paulo, 1994; v 2; p 1060.

49. Garrido, M. J. F.; Tesina para licenciada en Ciencias Químicas; U. Complutence, ICP del CSIC; Madrid, 1986.

50. Lopez-Gonzalez, J. D.; Deitz, V. R.; J. Research National Bureau Standars, 1952, 48, 325.

51. Mantell, C. L.; Adsorption; $2^{\text {th }}$ ed.; McGraw Hill; New York, 1951; p 44.

52. Engelhard; Raising performance standards in catalysts and sorbents for fats and oils; Engelhard; Houston, 1996.

53. Fuller's Earth Union; The Properties of Fuller's Earth and Some Uses of Fuller's Earth Products; Fuller's Earth Union Ltd.; Redhill, Survey, 1983.

54. Süd-Chemie; Bleaching Earths; Süd-Chemie Ag, München, 1995.

55. Süd-Chemie; Tonsil-Highly Active Bleaching Earths; SüdChemie Ag, München, 1998.

56. Ceca; Bentonites et Argiles Spéciales Clarsol; Ceca S. A; Velizy-Villac on Blay Cedex, 1986.

57. Harshaw-Filtrol; Filtrol Clay Products Typical Applications, Bulletin IC-161R; Harshaw-Filtrol; Cleveland, Ohio, 1987.

58. Alclor; Clarificação de Gorduras e Óleos: Uma Avaliação Técnico Econômica; Alclor-Química das Alagoas; Marechal Deodoro, AL, 1988.

59. Fulmont Argilas Ativadas; Fulmont-Argitex; Boletim Técnico BTFAOO; Jacareí, São Paulo, 1998.

60. Franchi, J. G.; Mangialardo, R. C.; Lazzari, R. T.; Vogt, J. C.; Fernandez, J. L.; Yoshida, R. In Industrial Minerals 92; Ciminelli, R. R., Ed; ABIM; Belo Horizonte, Brazil, $1991 ; \mathrm{p} 39$.

61. Souza-Santos, P.; Ciência e Tecnologia de Argilas; $2^{\text {th }}$ ed.; Editora Edgard Blücher; São Paulo, Brazil, 1992; v 2; Chap. 28.

62. Jovanovic, N.; Janackovic, J.; Appl. Clay Sci. 1991, 6, 59.

63. Srasra, E.; Bergaya, F.; vanDame, H.; Ariguib, N. K.; Appl. Clay Sci. 1989, 4, 411.

64. Moronta, A. J.; Bren, C. In Physical and Chemical Characterisation of Mineral Suspensions. Book of Abstracts; University of Bath; England, 1998; p 40. 
65. Breen, C.; Madejova, J.; Komadel, P.; Klapyta, Z. In Clays for Our Future, Book of Abstracts; Carleton University; Ottawa, Canada, 1997; p A11.

66. Breen, C.; Watson, R.; Appl. Clay Sci. 1998, 12, 479.

67. Brown, G., Ed.; The X-Ray Identification and Crystal Structures of Clay Minerals; Mineralogical Society; London, 1961.

68. Foster, M. D. In Proceedings of 3td National Conference on Clays and Clay Minerals; NAS Publication 395; 1955; p 205.

69. American Oil Chemists Society. AOCS Official Method Cc 8b-52. Bleaching Test. Revised 1979.

70. Siddiqui, M. K. H.; Bleaching Earths; Pergamon Press; Oxford, 1968; p 54.

71. Baraúna, O. S.; Souza-Santos, P.; Cerâmica 1996, 42, 256.

72. Baraúna, O. S.; Souza-Santos, P. In Anais do IV Encontro Nacional da Gipsita, Olinda, PE, 1997, v 1; p19.

73. Morgado, A. F.; Souza-Santos, P. In Abstracts of 1998 Meeting of the SME; Orlando, Florida, 1998; p 33.

74. Morgado, A. F.; Doctoral Thesis; Depto. de Engenharia Química, EPUSP, Escola Politécnica da Universidade de São Paulo; Brazil, 1998.

75. Souza-Santos, P.; Boletim Técnico Petrobrás 1963, 6, 117.

76. Ferreira, H. C.; Doctoral Thesis; Depto. de Engenharia Química; EPUSP, Escola Politécnica da Universidade de São Paulo; Brazil, 1972.

77. Baraúna, O. S.; Master's Dissertation; Centro de Tecnologia da Universidade Federal de Pernambuco; Recife, Brazil, 1991.

78. Baraúna, O. S.; Araújo, A. P. R.; Souza-Santos, P. In Anais $38^{\circ}$ Congresso Brasïleiro de Cerâmica; Blumenau, Santa Catarina, Brazil, 1994; v 1; p 263.

79. Palza, R. E.; Master's Dissertation; Instituto de Química, Universidade de São Paulo, São Paulo, Brazil, 1991.

80. Valenzuela-Díaz, F. R.; Ativação de Argilas Esmectíticas; Relatório ao PADCT; CEPED, Centro de Pesquisas e Desenvolvimento do Estado da Bahia; Salvador, Bahia, Brazil, 1989.

81. Zandonadi, A. R.; Doctoral Thesis; Instituto de Química, Universidade de São Paulo; São Paulo, Brazil, 1972.
82. Zandonadi, A. R.; Ferreira, H. C.; Souza-Santos, P.; Argilas Montmoriloníticas Brasileiras como Agentes Descorantes de Óleos Vegetais e Minerais; Publicação 1045 IPT, Instituto de Pesquisas Tecnológicas do Estado de São Paulo, São Paulo, São Paulo, Brazil, 1975.

83. Clemency, C. V. In Proceed. Intl. Clay Conf 1975; Applied Publishing; Wilmette, 1976; p 15.

84. Tanno, L. C.; Heilmeister Jr, Z.; Cabral Jr, M.; Motta, J. F. M.; Zandonadi, A. R.; Cerâmica 1997, 43, 43.

85. Souza-Santos, P.; Santini, P.; Cerâmica 1965, 11, 36.

86. Berg, E. A. T.; Cerâmica 1967, 12, 107.

87. Berg, E. A. T.; Souza-Santos, P.; Mineração e Metalurgia 1968, 46, 26.

88. Berg, E. A. T.; Doctoral Thesis; Depto. de Engenharia Química, EPUSP, Escola Politécnica da Universidade de São Paulo, São Paulo, São Paulo, Brazil, 1970.

89. Felipe, E. S.; Mapeamento geológico-geotécnico na região do Alto Iguaçu; MINEROPAR; Curitiba, Paraná, Brazil, 1994.

90. Formoso, M. L. L.; Ramos, A. N.; Alves, D. B. In Clays Controlling the Environment; Churchman, G. J., Ed.; CSIRO Publishing, Melbourne, 1995; p 421.

91. Figueiredo Filho, P. M.; Scarrone, A.; Rev. Bras. Tecnol. 1971, 2, 201.

92. Souza-Santos, P.; Souza-Santos, H.; Moniz, A. C.; Cerâmica 1962, 8, 2 .

93. Schardong, R.; Morgado, A. F. In Anais Salão Inic. Cient.; Porto Alegre, Rio Grande do Sul, Brazil, 1991; p 150.

94. Morgado, A. F., Moreira, R. F. P. M. In Anais XX Encontro Nac. Meios Porosos; São Carlos, São Paulo, Brazil, 1992; p J19.

95. Morgado, A. F.; Moreira, R. F. P. M.; Tirlone, F. K. In Anais $9^{\circ}$ Congresso Bras. Eng. Química; Salvador, Bahia, Brazil, 1992; p 325.

96. Morgado, A. F. In Anais II Congresso Italo-Brasileiro de Eng. Minas; São Paulo, São Paulo, Brazil, 1993; p 639. 97. Morgado, A. F.; Souza-Santos, P.; Cerâmica 1996, 42, 225. 